\title{
Immunoglobulin A Deficiency 1
}

National Cancer Institute

\section{Source}

National Cancer Institute. Immunoglobulin A Deficiency 1. NCI Thesaurus. Code C123434.

Decreased or absent levels of serum immunoglobulin A, with normal serum levels of immunoglobulin $\mathrm{G}$ and immunog lobulin $\mathrm{M}$ in a patient who is older than 4 years of age and in whom all other causes of hypogammaglobulinemia have been excluded. Affected individuals may be asymptomatic or have frequent infections, allergic reactions, or autoimmune disorders. 